\title{
4. CRETACEOUS PLANKTONIC FORAMINIFERS FROM THE NAURU BASIN, LEG 61, SITE 462, WESTERN EQUATORIAL PACIFIC ${ }^{1}$
}

\author{
Isabella Premoli Silva, Istituto di Paleontologia, Università di Milano, Piazzale Gorini 15, Milano, Italy \\ and \\ William V. Sliter, U.S. Geological Survey, National Center, Reston, Virginia
}

\begin{abstract}
Cretaceous planktonic foraminifers recovered from Deep Sea Drilling Project Site 462 in the Nauru Basin of the western equatorial Pacific Ocean range in age from near the Coniacian/Santonian boundary to middle Maestrichtian. Species from Hole 462 show this stratigraphic range, whereas those from Hole $462 \mathrm{~A}$ are Campanian and Maestrichtian in age. Assemblages are characterized by a small-sized, poorly preserved, low-diversity planktonic fauna, dominated by species of Hedbergella, Globigerinelloides, Archaeoglobigerina, Heterohelix, and Schackoina. Species of Globotruncana, Marginotruncana, Dicarinella, Praeglobotruncana, and other larger-sized genera are rare. Reworked species indicate the presence of upper Aptian, Cenomanian, and possible Turonian source areas that were not identified at Site 462. Benthic foraminifers and characteristics of the associated biogenic and lithologic constituents indicate that abyssal depositional environments greater than $\mathbf{4 0 0 0}$ meters and well below the calcite compensation depth existed throughout the Mesozoic interval represented by sediments from just above the volcanic complex of probable mid-Cretaceous age to those of the modern basin, with a water depth of 5,189 meters.
\end{abstract}

\section{INTRODUCTION}

Cretaceous foraminifers of Coniacian/Santonian to Maestrichtian age were recovered from Site 462 in the Nauru Basin, western equatorial Pacific (Fig. 1). The site was selected to sample Late Jurassic oceanic sediments, and to penetrate the basement at magnetic anomaly M-26, approximately 150 m.y. old. Hole 462 was drilled at a water depth of 5189 meters, and 376.8 meters of core were taken at a recovery rate of 61 per cent. The hole was terminated at Core 69 , in basalt sills, as the rate of penetration was very slow. Hole $462 \mathrm{~A}$ was offset from Hole 462 by 473 meters, and drilled to Core 92, at 1068.5 meters below sea floor. Operations were terminated in a thick volcanic complex of probable midCretaceous age.

Cretaceous planktonic foraminifers reported here are from Core 46, at a depth of 428 meters below sea floor, to Core 60, at 559 meters below sea floor (Hole 462), and from Core 7, at a depth of 439.5 meters below sea floor, to Core 2, at 564.2 meters below sea floor (Hole $462 \mathrm{~A}$ ). Hole 462 was continuously cored throughout, whereas Hole 462A was continuously cored only from Core 8 , at a depth of 487.0 meters below sea floor, to Core 24; above Core 8, the section was "washed" and spot cored. Despite the different methods of recovery, the two holes correlate very well, and most of the biostratigraphic events are detectable in both holes. Cretaceous sediments recovered from Site 462 represent a succession of fine-grained resedimented-carbonate layers that alternate with sediments devoid of carbonate. The carbonate content is very unevenly distributed throughout the Cretaceous sequence and is related pre-

\footnotetext{
${ }^{1}$ Initial Reports of the Deep Sea Drilling Project, Volume 61.
}

dominantly to the presence of calcareous nannoplankton, and to a lesser extent the amount of calcareous foraminifers, both planktonic and benthic.

In comparison to the Tertiary sequence, the autochthonous zeolitic claystones become more abundant in the Cretaceous sequence, and increase down-hole to become the dominant sediment type, where they finally intercalate with the volcanic complex.

Coarse to very-coarse volcaniclastic sediments are interbedded in the late Campanian to Maestrichtian portion of the Cretaceous sequence; they consist of volcanic rock fragments and shallow-water bioclasts, along with a fine fraction composed mainly of planktonic and small benthic foraminifers. These redeposited interbeds display a variety of structures, including graded bedding, cross-laminations, and parallel laminations.

\section{BIOSTRATIGRAPHY}

The occurrence of planktonic foraminifers at Site 462 is associated with layers of redeposited volcaniclastic material. The more-diverse assemblages are associated with the coarse-grained layers that contain shallowwater debris. Planktonic foraminifers from the finegrained layers are rare. Preservation of specimens in all sediment types from this deep basin, well below the Cretaceous CCD, is characteristically poor, and specimens are always strongly recrystallized. All assemblages exhibit varying degrees of size sorting, and most are composed of small-sized individuals.

Despite the obvious evidence of displacement, the distribution of foraminifers follows the "normal" succession of biostratigraphic events. Obviously, the transport mechanisms and timing were largely penecontemporaneous. Nevertheless, several points need to be considered: (1) there is no continuity from one assemblage to the next; (2) the first appearance of a taxon must be 


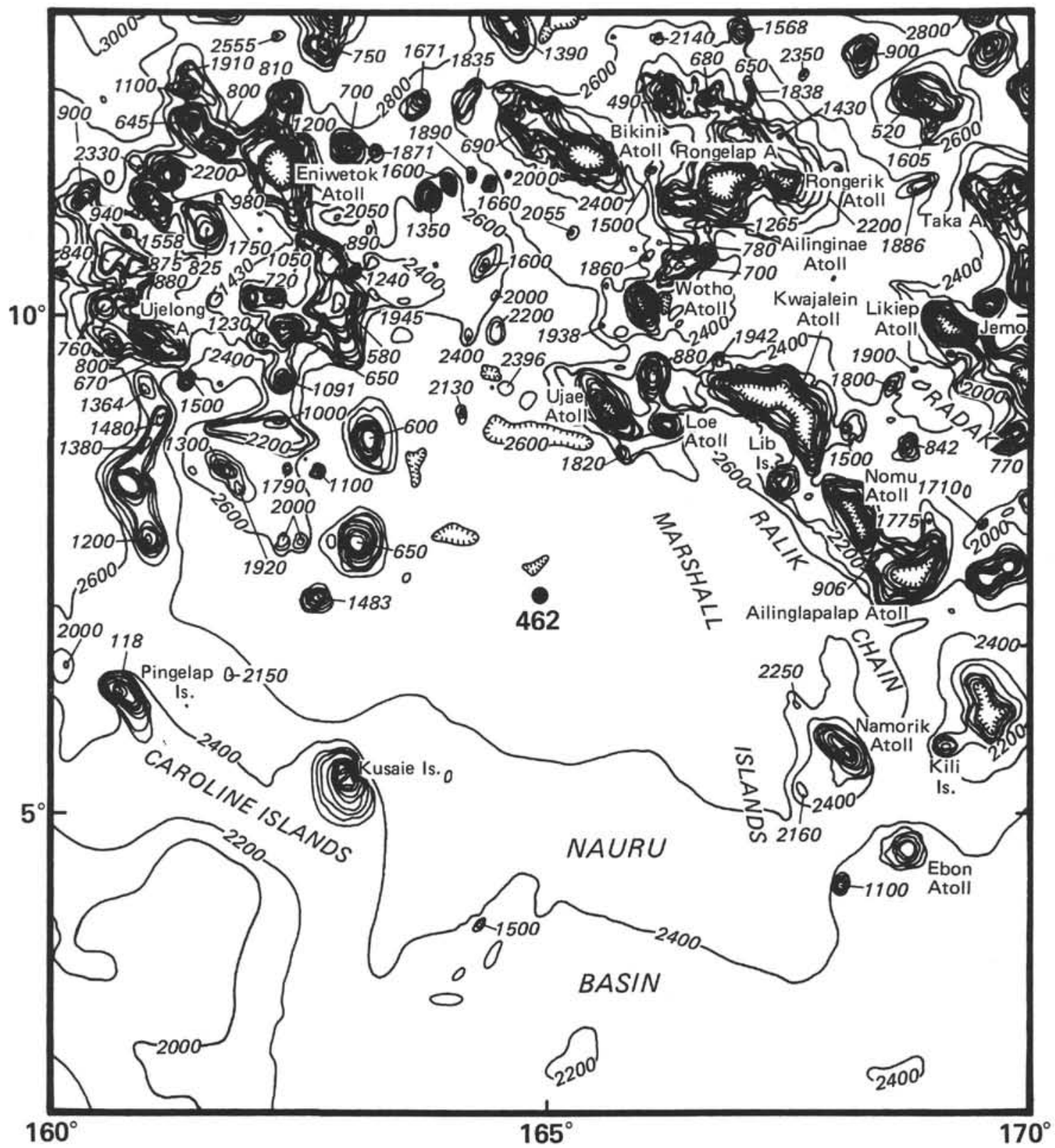

Figure 1. Location of DSDP Site 462 in the Nauru Basin.

considered a "local" event that may differ from the "actual" biostratigraphic event by some undefined time lapse; if the time lapse is short, the displaced assemblages will be similar in age to the autochthonous zeolitic claystones; and (3) reworking of older specimens, is a minor feature in the Cretaceous sequence.

The zonal scheme used in the present paper and the most important biostratigraphic events on which the biozones are based are shown in Figure 2. This zonal scheme is a combination of those by van Hinte (1976), Sigal (1977) and Premoli Silva and Boersma (1977).

The vertical distributions of planktonic foraminifers for both drill holes are plotted in Figures 3 and 4, which also include (1) the abundance and preservation of planktonic foraminifers, and (2) the abundance of other fossil groups. A list of identified species is given in Ap- pendix A. Samples which were barren of planktonic foraminifers are not included in the range charts, but are listed in Appendix B. Lithologically, the barren samples are composed mainly of clay and/or radiolarian sand. The zeolitic claystone layers often yield fish debris and abyssal noncalcareous benthic foraminifers.

In general, layers that yield planktonic foraminifers are much rarer in Hole $462 \mathrm{~A}$ than in Hole 462, in particular in the lower portion overlying the basalt. In fact, two biozones (Dicarinella concavata Zone and Globotruncana subspinosa Zone, of Coniacian to early Santonian and late Campanian age, respectively) were not identified in Hole 462A.

The biozones common to both holes are the Globotruncana gansseri Zone and Globotruncana tricarinata Zone, of Maestrichtian age, and the Globotruncana 
calcarata Zone and Globotruncana elevata Zone, of Campanian age. In Hole $462 \mathrm{~A}$, the last zone also includes the interval corresponding to the unidentified Globotruncana subspinosa Zone. Identification of the index species in the latter zone was not possible, because the only sample with abundant foraminifers (Core 8, Section $2,38 \mathrm{~cm}$ ) is too indurated to obtain isolated specimens, and the index species is not recognizable in thin section.

Size sorting or redeposition interferes considerably with the species composition. Most of the largest species, such as those belonging to the genera Globotruncana, Marginotruncana, and Dicarinella, according to their pertinent biostratigraphic positions on the sequence, are missing or are represented by a single specimen or a few immature specimens. Therefore, even the most diverse assemblages display a low diversity and are never fully representative of the tropical assemblages that would be expected from the paleolatitude inferred for Site 462. Small-sized species $(150 \mu \mathrm{m})$ are much more common, and in many cases are the only components of the planktonic-foraminifer assemblages. Among those species are representatives of the genera Globigerinelloides, Hedbergella, Pseudoguembelina, Heterohelix, and Schackoina. In some levels, schackoinids uncharacteristically made up a large part of the total assemblage; however, reworking from older levels may account for the anomalous abundance.

The biozones identified at Site 462 are as follows (from bottom to top):

\section{Dicarinella concavata Zone}

Definition: Interval from the appearance of the zonal marker to the appearance of Dicarinella asymmetrica.

Remarks: The index species was not found; however, the co-occurrence of Marginotruncana pseudolinneiana, M. renzi, and Hedbergella flandrini, associated with Archaeoglobigerina blowi, A. bosquensis, and Dicarinella canaliculata, is diagnostic of this zone. In particular, the co-occurrence of D. canaliculata and archaeoglobigerinids indicates the middle part of that long zone (i.e., near the Coniacian/Santonian boundary; see below).

Occurrence: Hole 462, Core 57, Section 3 to core-catcher; Hole 462A, not identified.

\section{Globotruncana elevata Zone}

Definition: Interval from the appearance of the zonal marker to the appearance of Globotruncana subspinosa.

Remarks: The zone was identified by the joint occurrence of the index species and Heterohelix globulosa, H. striata, H. pulchra, Globigerinelloides alvarezi, G. asper, and Hedbergella monmouthensis, all of which appear within the Globotruncana elevata Zone. Rare specimens of Globotruncana elevata appear higher in the section, but without the other members of the zonal assemblage. Samples with large specimens contain the index species associated with Globotruncana stuartiformis, G. fornicata, G. arca, and Pseudoguembelina costulata.

Occurrence: Hole 462, Core 55 to Core 53; Hole $462 \mathrm{~A}$, Core 9 to Core 8 , Section 1, 57-60 cm. Note that in Hole 462A the Globotruncana subspinosa Zone was not identified, and the corresponding interval was included in the $G$. elevata Zone.

\section{Globotruncana subspinosa Zone}

Definition: Interval from the appearance of the zonal marker to the appearance of Globotruncana calcarata.

Remarks: With the occurrence of the oldest coarser layers, the planktonic assemblages become more diverse and richer in larger-sized taxa. The index species occurs frequently and is associated with
Globotruncana caliciformis, G. rosetta, and Pseudotextularia elegans, among others.

Occurrence: Hole 462, Core 52, Section 3, 68-72 cm to core catcher. In Hole 462A, not identified (see above).

\section{Globotruncana calcarata Zone}

Definition: Range of the zonal marker.

Remarks: The index species is well represented, and the assemblages are diverse, with abundant specimens. Globotruncanella havanensis and Globotruncana plummerae appear within this zone. Coarser layers are common in this interval.

Occurrence: Hole 462 , Core 52 , Section $2,67-73 \mathrm{~cm}$ to the top of Core 51. Hole 462A, Core 8, Section 1, 35-40 cm to H3, CC, and in a pebble collected from Core 21 , Section $1,1-3 \mathrm{~cm}$.

\section{Globotruncana tricarinata Zone}

Definition: Interval from the disappearance of Globotruncana calcarata to the appearance of Globotruncana gansseri.

Remarks: In this interval rich assemblages alternate with poorly diversified assemblages. The upper boundary is poorly defined, and the occurrence of Pseudoguembelina excolata prior to the appearance of Globotruncana gansseri suggests that the upper part of this interval already belongs to the next zone, and that specimens of $G$. gansseri were excluded by size sorting.

Occurrence: Hole 462 , Core $50 \mathrm{CC}$ to top of Core 49 . Hole $462 \mathrm{~A}$, Core H3, Section 3, 75-79 $\mathrm{cm}$ to top of Core H3.

\section{Globotruncana gansseri Zone}

Definition: Interval from the appearance of the zonal marker to the appearance of Globotruncana contusa. The index species is common and is associated in some levels with Globotruncana gagnebini and G. aegyptiaca. Heterolicidae and Globigerinelloides are always very common in the finer fractions. The richest assemblages are associated with the coarser layers.

Occurrence: Hole 462, Core 48 and chips from Core 47 and 46; Hole 462A, Core 7, Section 1.

Chronostratigraphically, the Globotruncana elevata, Globotruncana subspinosa, and Globotruncana calcarata Zones correspond to the Campanian, which appears to be complete in Holes 462 and $462 \mathrm{~A}$. This is confirmed by the occurrence of a magnetic reversal in Core 462-55 and in Core 462A-9. This event correlates with the ocean-floor magnetic reversal between Anomalies 33 and 34 (at the top of the Long Cretaceous Normal). According to recent data (see Supko, Perch-Nielsen, et al., 1977, and Alvarez et al., 1977), the ocean-floor reversed interval is just above the Santonian/Campanian boundary.

The Globotruncana tricarinata and Globotruncana gansseri Zones are correlated with the early and middle Maestrichtian, respectively. In both holes, planktonicforaminifer assemblages attributable to the upper most zones of the Maestrichtian are missing, which suggests a hiatus than spans the late Maestrichtian and the early Paleocene (see Thierstein, this volume; Premoli Silva and Violanti, this volume).

As mentioned in the description of the zone, only part of the Dicarinella concavata Zone is documented from Hole 462. This zone spans the interval from the early Coniacian to the base of the late Santonian. The recorded assemblages appears to document the middle part of the zone, which is correlated with an interval straddling the Coniacian/Santonian boundary.

Correlation of the Cretaceous cores from Leg 61 is summarized in Figure 5. As discussed above, Cores 51 to 52 , Section 2 of Hole 462 are thought to be equivalent to Core 8 , Section 1 to $9, \mathrm{CC}$ of Hole $462 \mathrm{~A}$. Correlations of the younger cores from both holes are as shown. 


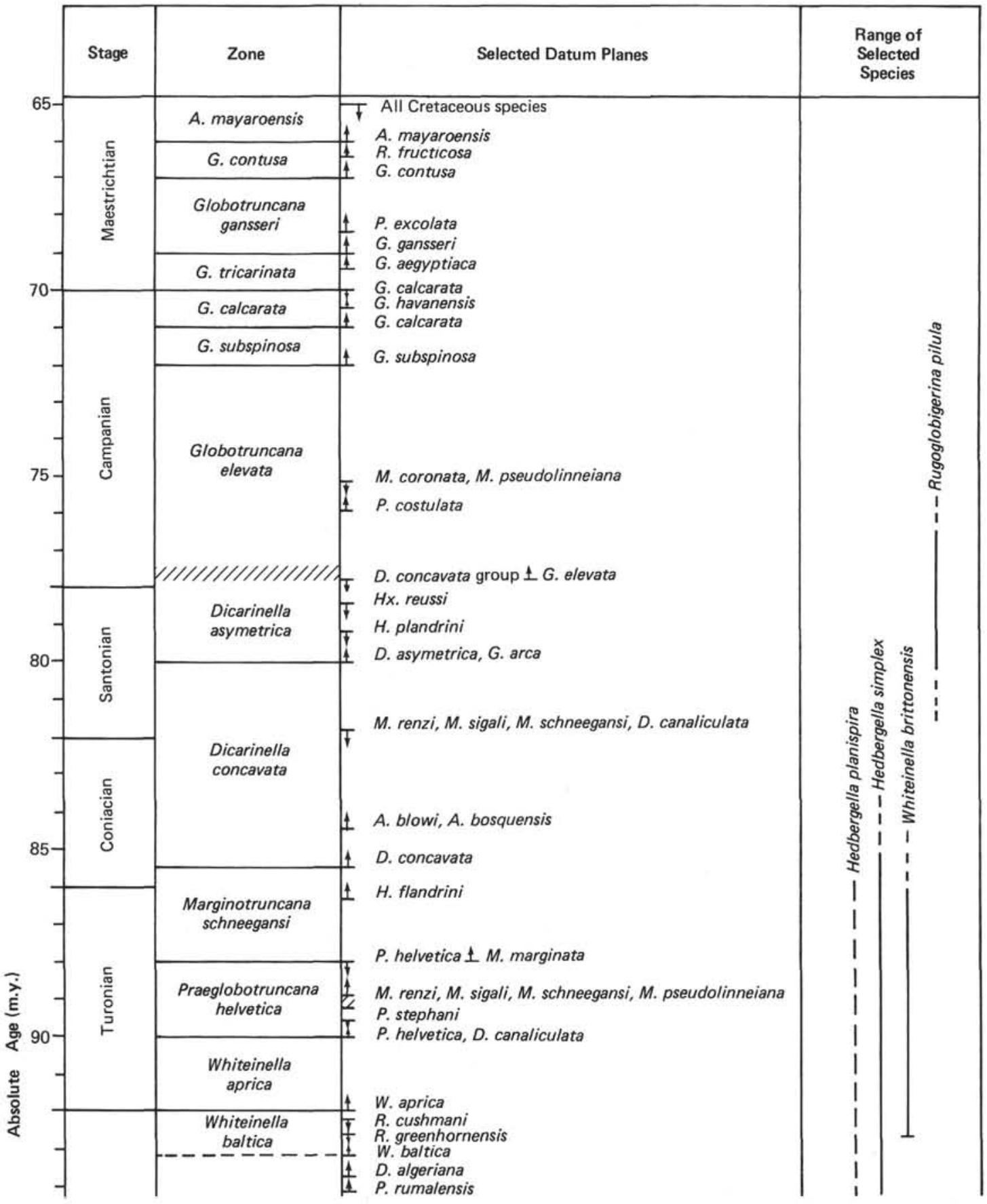




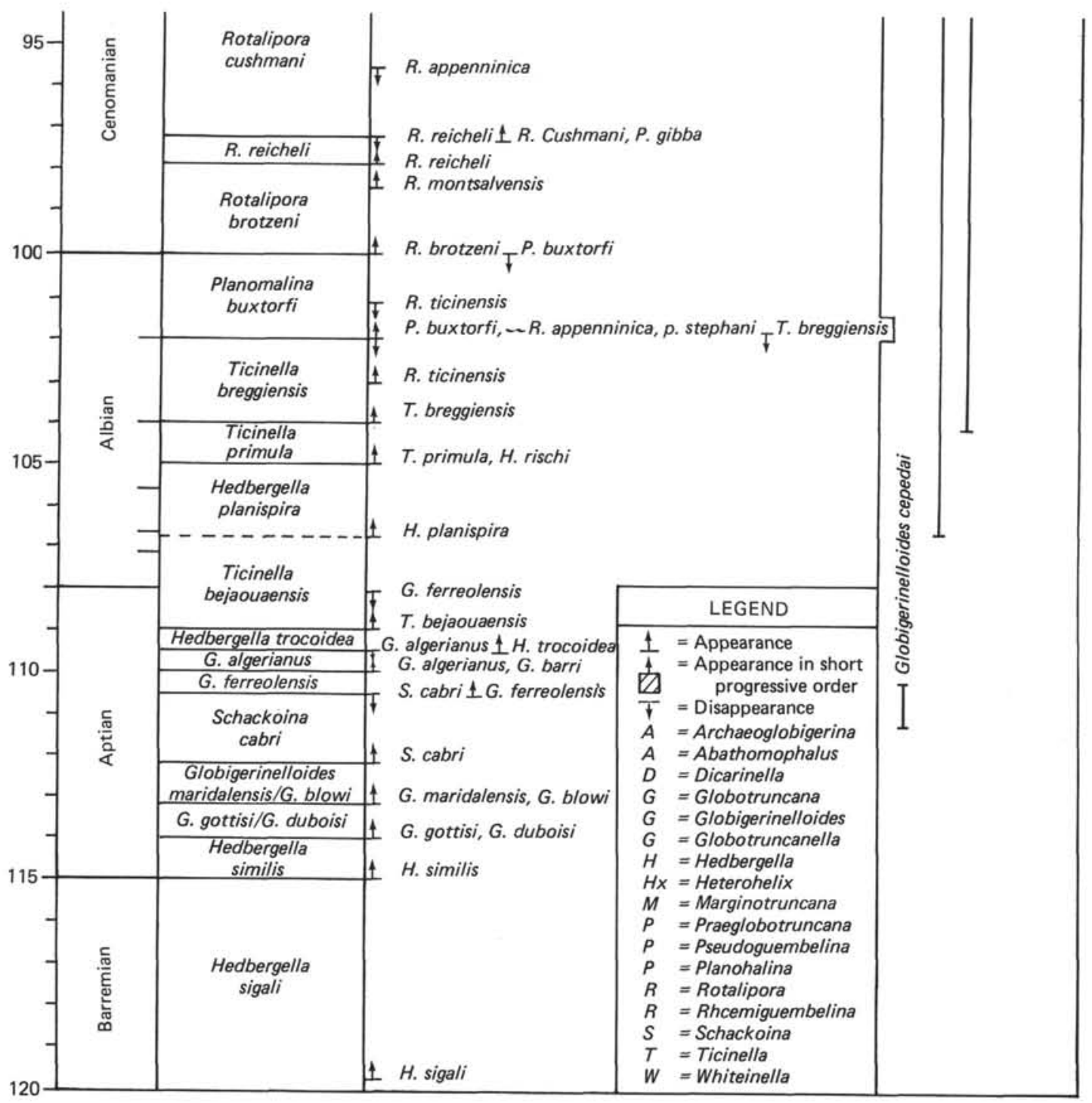

Figure 2. Planktonic-foraminifer zones, selected datum levels, and ranges of selected species. The zonal scheme is after van Hinte (1976), Sigal (1977), and Premoil Silva and Boersma (1977). 


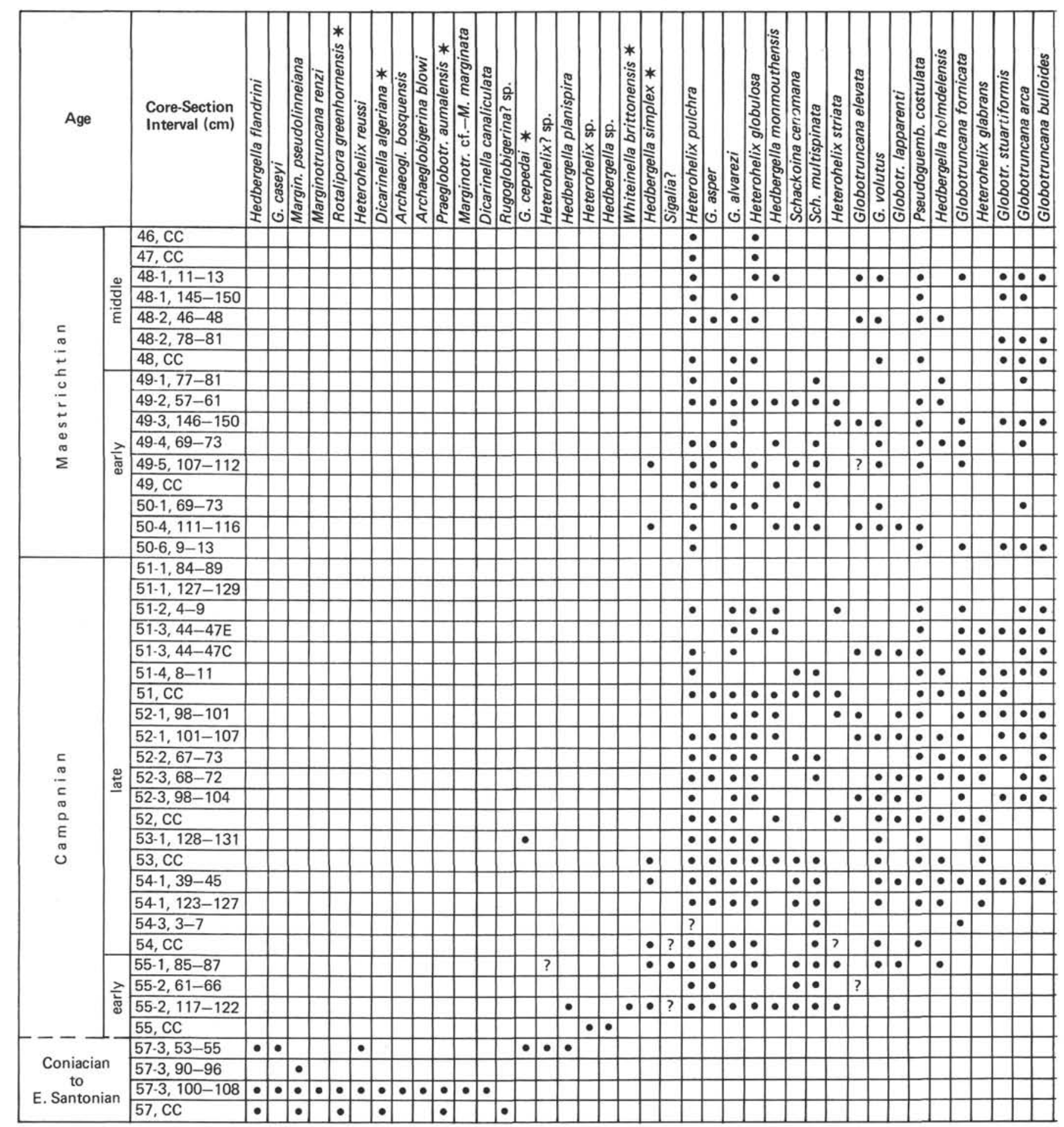

Figure 3. Distribution of Cretaceous planktonic foraminifers and associated organisms from Hole 462 . Reworked species are identified in the species list. 


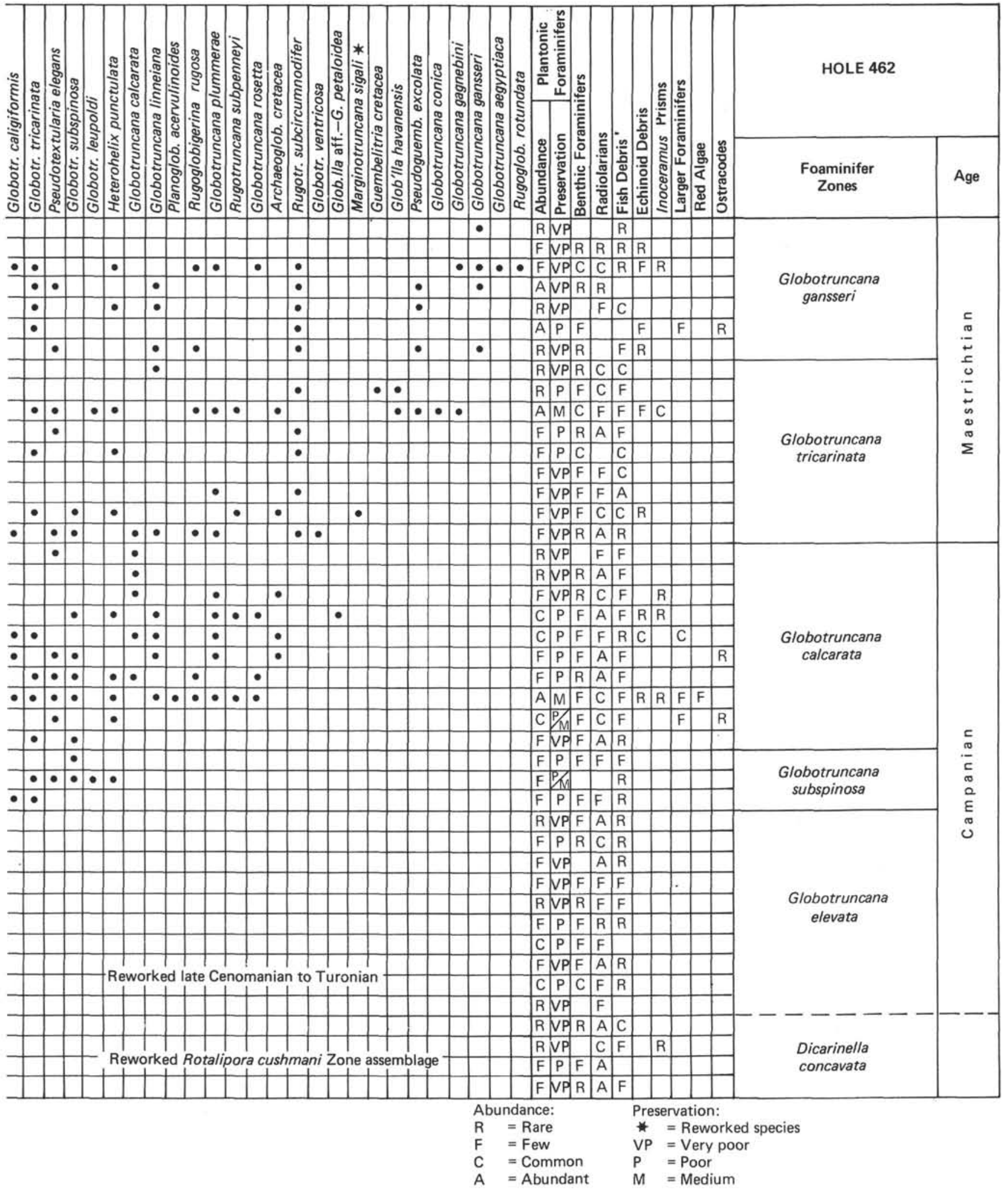

Figure 3. (Continued). 


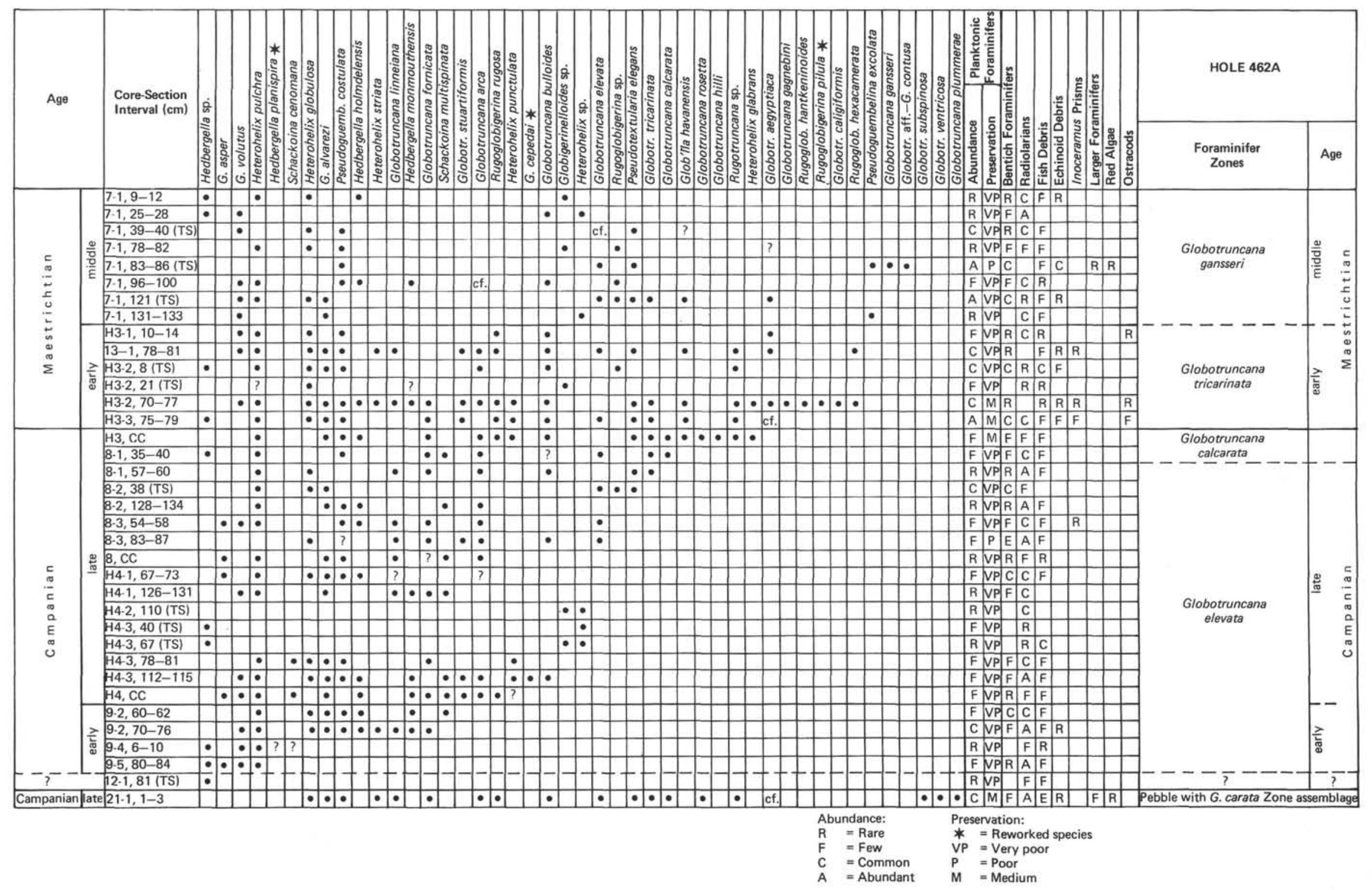

Figure 4. Distribution of Cretaceous planktonic foraminifers and associated organisms from Hole 462A. Reworked species are identified in the species list. 


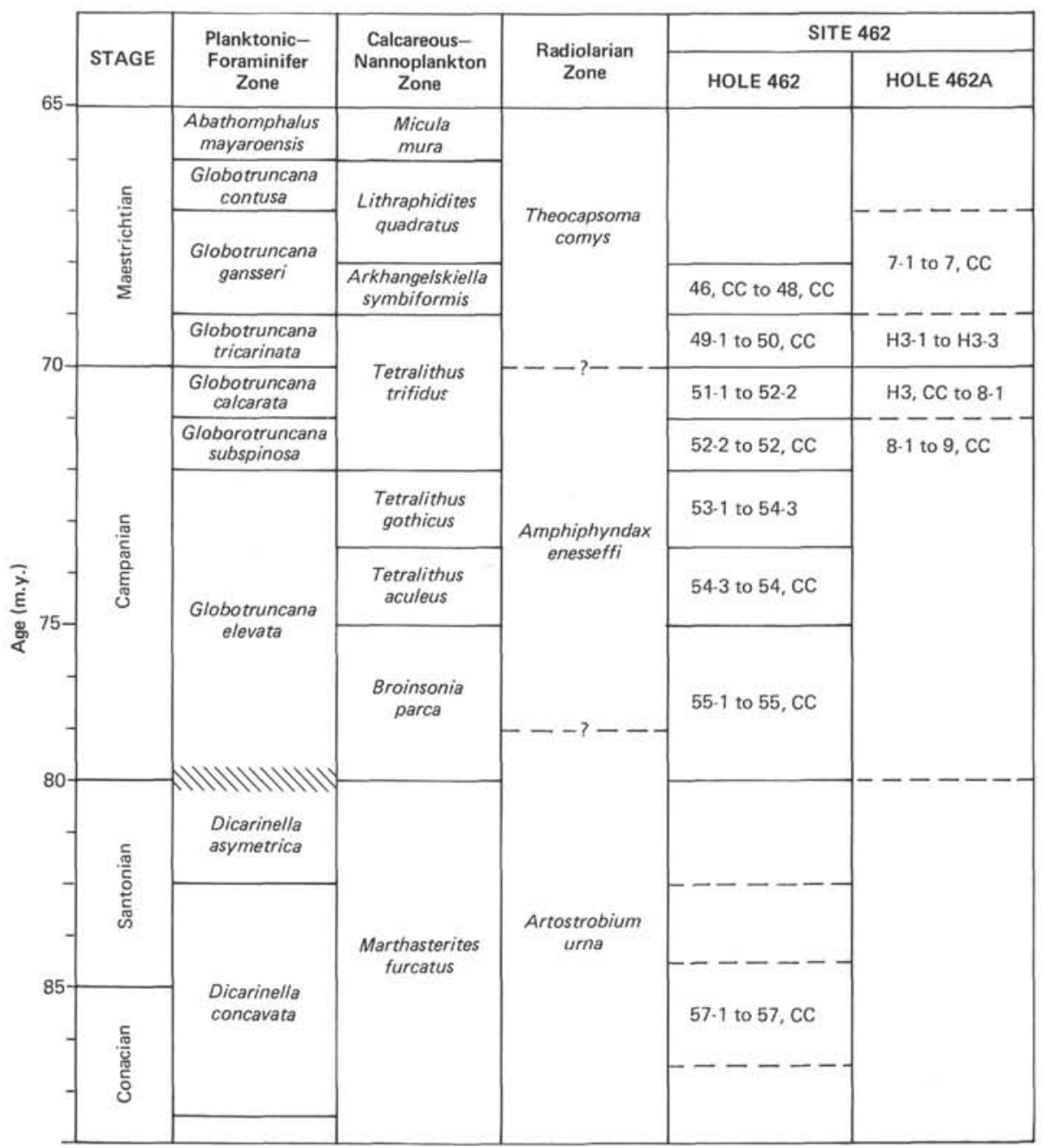

Figure 5. Stratigraphic correlation of Mesozoic cores from Site 462 that contain planktonic foraminifers. Shown are the zonations for the planktonic foraminifers, calcareous nannoplankton, and radiolarians from Site 462 .

\section{REWORKED PLANKTONIC ASSEMBLAGES}

Additional information about the Cretaceous assemblage is provided by older species displaced higher in the section. We confine the following remarks to species recorded from the Cretaceous portions of Site 462. Cretaceous assemblages occurring in the Tertiary portion are discussed by Premoli Silva and Violanti. (this volume).

Reworked species are included in the range charts for each hole (see Figs. 3 and 4); however, they are marked to distinguish them from penecontemporaneous species. To lend additional support to our biostratigraphic interpretation, the ranges of selected reworked species are plotted against the zonal scheme (Fig. 2). It is worth mentioning that reworking in both holes comes from the same intervals and occurs at the same level, although at Hole 462 reworked species are more abundant than those from Hole 462A. We recognize the following zones (from older to younger) based on the reworked species:
1) Schackoina cabri/Globigerinelloides ferreolensis zonal boundary, upper Aptian, on the basis of the occurrence of Globigerinelloides cepedai in Hole 462, Core 57, Section 3, 53-55 cm, from the Dicarinella concavata Zone (late Coniacian to early Santonian); Core 53, Section 1, 128-131 cm, from the Globotruncana elevata Zone (late Campanian).

2) Rotalipora cushmani Zone, middle to late Cenomanian, on the basis of the occurrence of Rotalipora greenhornensis, Dicarinella algeriana, Praeglobotruncana aumalensis, and Hedbergella planispira: Hole 462, Core 57 , from the Dicarinella concavata Zone (late Coniacian to early Santonian); Hedbergella planispira occurs alone in Hole 462, Core 55, Section 2, 117-122 $\mathrm{cm}$, from the Globotruncana elevata Zone (early Campanian); this species disappears within the Rotalipora cushmani Zone (middle part); however, reworking from older levels cannot be ruled out.

3) Rotalipora cushmani/Praeglobotruncana helvetica zonal boundary or younger, latest Cenomanian to early Coniacian, on the basis of the co-occurrence of 
Hedbergella simplex and Whiteinella brittonensis: Hole 462 , Core 55, Section 2, 117-122 cm, from the Globotruncana elevata Zone (early Campanian).

4) "Praeglobotruncana" helvetica Zone (middle part) to Dicarinella concavata Zone (lower part), middle Turonian to early Santonian, on the basis of the occurrence of Marginotruncana sigali: Hole 462, Core 50, Section 4, 111-116 cm, from the Globotruncana tricarinata Zone (early Maestrichtian); this species is associated in this sample with Hedbergella simplex, which should become extinct at the base of the $D$. concavata Zone (early Coniacian); if the two species were derived from the same reworked level, rather than the interval involved here, then the reworking would be limited to the Turonian; Hedbergella simplex occurs alone in Hole 462 , Cores 55 through 53, from the Globotruncana elevata Zone, and in Cores 50 and 49, from the Globotruncana tricarinata Zone (early Maestrichtian); because of its long stratigraphic range (from the Albian to the base of the Coniacian), its presence cannot be used to establish precisely the biozone represented in the reworking.

In Hole 462A, reworking comparable in age to that mentioned from Hole 462 occurs in Core H4, section 1 , 126-131 cm, from the Globotruncana elevata Zone, where a specimen of Hedbergella sp. is recovered. Rugoglobigerina pilula, ranging from the middle part of Dicarinella concavata Zone to the base of the Globotruncana elevata Zone (late-early Santonian to early Campanian), occurs in Core $\mathrm{H3}$, section $2,70-77 \mathrm{~cm}$, from the Globotruncana tricarinata Zone (early Maestrichtian). This level can be compared with that from Hole 462 in which Marginotrucana sigali occurs.

It should be mentioned that some of the reworked species are recorded here for the first time from the Pacific Area.

\section{BENTHIC ENVIRONMENTS}

Cretaceous sediments at Site 462 were deposited at abyssal depths greater than 4000 meters, as indicated by the biogenic and lithologic constituents. Of particular importance are the agglutinated foraminifers typical of the reddish-brown zeolitic claystone of both holes.

These assemblages include species of Hyperammina, Haplophragmoides, Praecystammina, Paratochamminoides, Glomospira, and Ammodiscus, among others, that are usually associated with fish debris, recrystallized radiolarians, and sponge spicules. This biogenic association is interpreted to represent deep-water benthic environments between 5000 and 6000 meters, such as those reported previously from Mesozoic sediments in the western Pacific during DSDP Leg 20 (Krasheninnikov, 1973), the Indian Ocean during Leg 27 (Krasheninnikov, 1974), and the South Atlantic during Leg 39 (Sliter, 1977). This autochthonous assemblage is typical of the zeolitic claystone of Cores 56 to 60 in Hole 462, and Core 10 to Core 13, Section 1 of Hole 462A. Above these intervals and into the Cenozoic section, the assemblage is found in the reddish claystone between turbidites, and as resedimented debris in the "pelagic" turbidites of the Oligocene to Miocene sediments in Cores 5 to 39 of Hole 462 . It is clear that deep-water environments analogous to those of the present Nauru Basin and well below the existing level of calcite dissolution existed at this locality at least since late Early Cretaceous time.

The autochthonous assemblage in Hole 462 continues unmixed above the basalt complex until Core 57, within this core is the first occurrence of allochthonous calcareous and agglutinated species from neritic and bathyal environments. Beginning at this level, in the early Santonian to Coniacian, the allochthonous species reappear in Core 55 and are found sporadically thereafter throughout the Cretaceous sequence, typically in association with displaced volcaniclastic sediments.

The allochthonous assemblage consists of rare, small, size-sorted, poorly preserved benthic species of Praebulimina, Gavelinella, Gyroidinoides, Stilostomella, Allomorphina, Ellipsonodosaria, and Pleurostomella, among others, which indicate bathyal source areas above 2500 meters. These assemblages are distinct from those with large calcareous foraminifers from neritic or reef environments described by Premoli Silva and Brusa (this volume). The smaller allochthonous assemblage represents extremely distal material that was transported into and preserved in the Cretaceous basin. Consequently, sorting mechanisms exert a strong influence on the recovery, character, and preservation of the assemblage. This influence is seen in the sporadic distribution and small size of the allochthonous species.

The allochthonous assemblage was again recovered from cores in Hole 462A. This assemblage was first noted in Core 12, Section 1, and continues sporadically above.

\section{COMPARISON WITH OTHER DSDP SITES}

Of the Cretaceous interval recovered during Leg 61 (Turonian to Maestrichtian), the Turonian to Santonian portion is most noteworthy because of its rarity in DSDP and on-shore localities. Comparison with other DSDP sites at which this interval was recovered reveals several faunal similarities. In the Pacific Ocean, Site 171 of Leg 17 contained a Cenomanian to Maestrichtian section from Horizon Guyot of the Mid-Pacific Mountains that included Marinotruncana renzi and $M$. sigali (Douglas, 1973). Site 310 A of Leg 32, drilled on Hess Rise, included a Cenomanian to early Campanian section with Praeglobotruncana aumalensis, Globotruncana lapparenti, and Marginotruncana sigali (Caron, 1975).

In the North Atlantic, the foraminifer assemblage from Site 136 of Leg 14, drilled north of Madeira, indicated an Albian to Coniacian-Santonian section with Archaeoglobigerina boquensis, Dicarinella canaliculata, Globotruncana linneiana, and Marginotruncana renzi, among others (Beckman, 1972).

Site 146 of Leg 15, in the Venezuela Basin, contained a similar Mesozoic interval that ranged from late Turonian to late Maestrichtian. Foraminifers were more diverse and abundant, and representative of a tropical assemblage. Joint occurrences among material of Leg 61 include Archaeoglobigerina blowi, A. bosquensis, Globotruncana lapparenti, Marginotruncana margin- 
ata, $M$. renzi, and $M$. sigali, among others. These same species were also recovered from a Turonian to Santonian section of the Venezuela Basin at Site 150 of Leg 15. Site 152 included Archaeoglobigerina blowi from a Campanian to Maestrichtian section on Beata Ridge of the Caribbean Sea (Premoli Silva and Bolli, 1973).

In the South Atlantic, Site 364 of Leg 40 produced a lower Albian to Campanian interval from the Angola Basin with Hedbergella flandrini, Archaeoglobigerina blowi, Globotruncana lapparenti, Marginotruncana renzi, and $M$. sigali (Caron, 1978). On Leg 39, in the western South Atlantic, Sites 356 and 357 contain faunal similarities. Site 356, on the Sao Paulo Plateau, contains a late Albian to Maestrichtian section with Hedbergella flandrini, Archaeoglobigerina blowi, A. bosquensis, Globotruncana lapparenti, Marginotruncana marginata, and $M$. sigali. Site 357 , on the Rio Grande Rise, produced a Santonian to Maestrichtian section with the same assemblage, minus Archaeoglobigerina bosquensis (Premoli Silva and Boersma, 1977). At Site 327 of Leg 36, on the Falkland Plateau, Archaeoglobigerina bosquensis was recovered from an early Albian to Maestrichtian interval (Sliter, 1977).

In the Indian Ocean, Site 258 of Leg 26, on the Naturaliste Plateau off southwestern Australia, included Archaeoglobigerina bosquensis, Dicarinella algeriana, and Marginotruncana marginata from an Albian to Santonian sequence (Herb, 1974).

\section{TAXONOMIC NOTES ON SELECTED SPECIES \\ Archaeoglobigerina blowi Pessagno, 1967 \\ (Plate 2, Figs. 1, 2)}

1967 Archaeoglobigerina blowi Pessagno, p. 326, pl. 59, figs. 1-10; pl. 94, figs. 2-3.

Rare specimens displaying 4 globular chambers in the last whorl, with hispid surface except in the last chambers, are attributed to $A$. blowi, even if the primary aperture looks extended extra-umbilically. We interpreted that the aperture is artifically enlarged.

\section{Archaeoglobigerina bosquensis Pessagno, 1967}

(Plate 2, Figs, 3, 4, 8)

1967 Archaeoglobigerina bosquensis Pessagno, p. 316, pl. 60, figs. $7-12$

Serval specimens with $51 / 2$ to 6 globular chambers in the last whorl and with a hispid surface are similar to $A$. bosquensis Pessagno. They differ from the typical specimens in having a larger aperture extended outside the umbilicus. As in the previous species, the aperture appears artificially enlarged.

\section{Dicarinella algeriana (Caron), 1966}

(Plate 2, Figs. 5, 6)

1966 Praeglobotruncana algeriana Caron, p. 74.

Poorly preserved, low, trochospiral specimens with 5 chambers in the last whorl that are petaloid on the spiral side and triangular on the umbilical side, with a truncated to compressed periphery, display strong similarities with Dicarinella algeriana.

\section{Dicarinella canaliculata (Reuss), 1854}

(Plate 2, Figs. 9, 10)

1854 Rosalina canaliculata Reuss, p. 70, pl. 26, figs. 4a, b (fide Ellis and Messina).

This species is one of the best represented from the assemblages in Hole 462, Core 57 , Section $1,100-108 \mathrm{~cm}$. In addition to the typical specimens, some individuals display slightly thickened and curved sutures on the umbilical side and are interpreted as forms transitional to Marginotruncana pseudolinneiana Pessagno, 1967, in agreement with the description reported in the MCE Atlas (1979).

\section{Hedbergella flandrini Porthault, 1979}

(Plate 1, Figs. 5, 8, 9)

1970 Hedbergella flandrini Porthault, p. 64, pl. 10, figs. 1-3.

Typical hedbergellids with 5 to 6 chambers that are pustulate on both sides and having a compressed periphery are attributed to Hedbergella flandrini Porthault.

\section{Marginotruncana sp. ef. M. marginata Reuss, 1845}

(Plate 2, Figs. 11, 14)

1845 Rosalina marginata Reuss, p. 36 , pl. 8 , figs. $54 \mathrm{a}, \mathrm{b}, 74 \mathrm{a}$; pl. 13 , figs. 68a, b. (fide Pessagno, 1967).

A single specimen with 2 keels, $51 / 2$ chambers inflated on both sides, that increase rather rapidly in size as added, and separated by depressed to partially raised curved sutures, with an extraumbilical-umbilical aperture, is close to Marginotruncana marginata. However, the poor preservation associated with the small-sized specimens and the irregularly increasing size of the chambers prevent us from fully identifying our specimen with the Reuss taxon.

\section{Praeglobotruncana aumalensis Sigal, 1952}

(Plate 1, Figs. 12, 13)

1952 Globigerina aumalensis Sigal, p. 28, pl. 29.

Rare specimens with gently compressed petaloid chambers, whose surfaces are covered by abundant pustules, at least on the umbilical side, are attributed to Praeglobotruncana aumalensis. A specimen illustrated in Figures 12 and 13 of Plate 1 displays similar, but less developed features than the typical $P$. aumalensis, and may be a primitive form.

Other (even rare) specimens display a large concentration of pustules along the sutures of the spiral side, which appear raised and keel-like. On the characteristics of the of umbilical side and the lack of a true keel, these specimens are tentatively related to Praeglobotruncana aumalensis, and are figured in Plate 1, Figures 10 and 11, as Preaglobotruncana sp. aff. P. aumalensis.

\section{Globigerinelloides cepedai (Obregon), 1959}

(Plate 1, Fig. 4)

1959 Hastigerinelloides cepedai Obregon, p. 151, pl. 4, fig. 5 (fide Longoria, 1974).

Very rare, small, planispiral specimens that are slightly biumbilicate, with 5 elongated chambers having a single spine, at least in the last chamber, are recorded from the Golobotruncana elevata Zone (Campanian) and are attributed to Globigerinelloides cepedai (Obregon). Confirmation of this identification would indicate reworking from Aptian layers.

\section{REFERENCES}

Alvarez W., et al., 1977. Upper Cretaceous-Paleocene magnetic stratigraphy at Gubbio, Italy. V. Type section for the Late CretaceousPaleocene geomagnetic reversal time scale. Geol. Soc. Am. Bull., $88: 383-389$.

Atlas des Foraminifères planctoniques du Crétacé moyen (Mer Boréale et Tetyhs), 1979. Cahiers de Micropaleontologie, 1,2: $1-366$.

Beckman, J. P., 1972. The foraminifera and some associated microfossils of Site 135-144. In Hayes, D. E., Pimm, A. C., et al., Init. Repts. DSDP, 14: Washington (U.S Govt. Printing Office), 389-420.

Bolli, H. M., Loeblich, J. R., and Tappan, H., 1957. Studies in foraminifera: planktonic foraminiferal families Hantkenidae, Orbulinidae and Globotruncanidae. Bull. U.S. National Mus., 215: 3-50.

Caron, M., 1966. Glootruncanidae du Cretace superieur du synclinal de la Gruyere (Prealpes medianes, Suisse). Rev. Micropalent., 9:68-93.

1975. Late Cretaceous planktonic foraminifera from the northwestern Pacific: Leg 32 of the Deep Sea Drilling Project. In 
Larson, R. L., Moberly, R., et al., Init. Repts. DSDP, 32: Washington (U.S. Govt. Printing Office), 719-724.

1978. Cretaceous planktonic foraminifers from Deep Sea Drilling Project Leg 40, southeastern Atlantic Ocean. In Bolli, H. M., Ryan, W. B. F., et al., Init. Repts. DSDP, 40: Washington (U.S. Govt. Printing Office), 651-678.

Donze, P., Porthault, B., et al., 1970. Le Senonien inferieur de PugetTherniers (Alpes Maritimes) et sa microfaune. Geobios, 3(2):1-41.

Douglas, R. G., 1973. Benthonic foraminifera biostratigraphy in the central North Pacific, Leg 17, Deep Sea Drilling Project. In Winterer, E. L.,Ewing, J. I., et al., Init. Repts. DSDP, 17: Washington (U.S. Govt. Printing Office), 607-694.

Herb, R., 1974. Cretaceous planktonic foraminifera from the eastern Indian Ocean. In Davies, T. A., Luyendyk, B. P., et al., Init. Repts. DSDP, 26: Washington (U.S. Govt. Printing Office), 745-769.

Krasheninnikov, V. A., 1973. Cretaceous Benthic Foraminifera, Leg 20, Deep Sea Drilling Project. In Heezen, B. C., MacGregor, I. D., et al., Init. Repts. DSDP, 20: Washington (U.S. Govt. Printing Office), 205-219.

1974. Upper Cretaceous benthnic agglutinated foraminifera, Leg 27 ofthe Deep Sea Drilling Project. In Veevers, J. J., Heirtzler, J. R., et al., Init. Repts. DSDP, 27: Washington (U.S. Govt. Printing Office), 631-662.

Longoria, J. F., 1974. Stratigraphic, morphologic and taxonomic studies of Aptian planktonic foraminifera. Rev. Esp. Micropaleont., (no. extra Diciembre 1974):1-134.

Pessagno, E. A., Jr., 1967. Upper Cretaceous planktonic foraminifera from the Western Gulf coastal plain. Paleontogr. Am., 37:1-445.

Porthault, B., 1974. Le Cretace superieur de la "fosse vocontienne" et des regions limitrophes (France, Sud-Est) [these]. Lyon.

Premoli Silva, I., and Boersma, A., 1977. Cretaceous planktonic foraminifera of DSDP Leg 39, South Atlantic. In Supko, P. R., Perch-Nielsen, K., et al., Init. Repts. DSDP, 39: Washington (U.S. Govt. Printing Office), 615-641.

Premoli Silva, 1., and Bolli, H. M., 1973. Late Cretaceous to Eocene planktonic foraminifera and stratigraphy of Leg 15 sites in the Caribbean Sea. In Simpson, E.S.W., Schlich, R., et al., Init. Repts. DSDP, 25: Washington (U.S. Govt. Printing Office), 499-547.

Sigal, J., 1977. Essai de zonation du Crétacé méditerraneen à l'aidé des foraminifères planctoniques. Géol. Médit., 4:99-108.

Sliter, W. V., 1968. Upper Cretaceous foraminifera from Southern California and northwestern Baja California, Mexico. Kansas Univ. Paleont. Contr., 7:657-697.

1977. Cretaceous foraminifera from the southwestern Atlantic Ocean, Leg 36, Deep Sea Drilling Project. In Barker, P. F., Dalziel, I. W. D., et al., Init. Repts. DSDP, 36: Washington (U.S. Govt. Printing Office), 519-545.

Supko, P. R., Perch-Nielsen, K. et al., 1977. Init. Repts. DSDP, 39: Washington (U.S. Govt. Printing Office).

van Hinte, J. E., 1976. A Cretaceous time scale. Bull. Am. Assoc. Petrol. Geol., 60:498-516.

\section{APPENDIX A}

\section{List of Identified Species}

Archaeoglobigerina blowi Pessagno, 1967. Pessagno, 1967, p. 316, pl. 59, figs. 1-10; pl. 94, figs. 2-3.

Archaeoglobigerina bosquensis Pessagno, 1967. Pessagno, 1967, p. 316 , pl. 60 , figs. $7-12$.

Archaeoglobigerina cretacea (d'Orbigny), 1840. Pessagno, 1967, p. 317 , pl. 70, figs. $3-8$; pl. 94 , figs. $4-5$.

Dicarinella algeriana (Caron), 1966. Atlas, 1979/2, p. 57, pl. 50, figs. 1a-c, 2a-d.

Dicarinella canaliculata (Reuss), 1854. Atlas, 1970, v. 2, p. 67, pl. 53, figs. 1-3.

Globigerinelloides alvarezi (Eternod Olvera), 1959. Sliter, 1968, p. 98, pl. 15 , figs. 1,2 .

Globigerinelloides asper (Ehrenberg), 1854. Pessagno, 1967, p. 274, pl. 60 , figs. 4,5 .

\footnotetext{
${ }^{1}$ In alphabetical order by genera and species, and listing reference illustrations.
}

Globigerinelloides caseyi (Bolli, Loblich, and Tappan), 1957. Bolli, Loeblichand Tappan, 1957, p. 24, pl. 1, figs. 4a-5b.

Globigerinelloides cepedai (Obregon), 1959. Longoria, 1974, p. 7, pl. 7 , figs. 1, 2, 3-5; pl. 9, figs. 1-3.

Globigerinelloides volutus (White), 1928. Pessagno, 1967, p. 278, pl. 62 , figs. $9-11 ;$ pl. 100 , fig. 9.

Globotruncana aegyptiaca Nakkady, 1950. Pessagno, 1967, p. 319, pl. 79 , figs. $2-4$; pl. 83 , figs. $8-10$; pl. 94 , fig. 6 ; pl. 95 , figs. 8,9 . Globotruncana arca (Cushman), 1926. Pessagno, 1967, p. 79, figs. 58 ; pl. 90, figs. 6-8; pl. 96, figs. 7, 8, 17.

Globotruncana bulloides Vogler, 1931. Pessagno, 1967, p. 324, pl. 64, figs. 15-17.

Globotruncana calcarata Cushman, 1972. Pessagno, 1967, p. 326, pl. 64 , figs. $18-20$.

Globotruncana caliciformis Vogler, 1941. Ellis and Messina, 1949, as Globotruncana linnei caliciformis.

Globotruncana conica White, 1928. Pessagno, 1967, p. 328, pl. 65, figs. $8-10$; pl. 82 , figs. $1-5$.

Globotruncana elevata (Brotzen), 1934. Pessagno, 1967, p. 336, pl. 78 , figs. $12-14$; pl. 81 , figs. $9-14$.

Globotruncana fornicata 1931. Pessagno,1967, p. 336, pl. 78, figs. 12-14; pl. 81, figs. 9-14.

Globotruncana gagnebini Tilev, 1951. Premoli Silva and Bolli, 1973, p. 525 , pl. 6 , figs. $2-6$.

Globotruncana gansseri Bolli, 1951. Pessagno, 1967, p. 341, pl. 75, fig. 1 ; pl. 92 , figs. $13-18$.

Globotruncana hilli Pessagno, 1967. Pessagno, 1967, p. 343, pl. 64, figs. 9-14.

Globotruncana lapparenti Bolli, 1954. Pessagno, 1967. p. 344, pl. 71, figs. 6-13.

Globotruncana leupoldi Bolli, 1945. Premoli Silva and Bolli, 1973, pl. 525; Caron, 1972, p. 555, pl. 2, figs. 1a, b.

Globotruncana linneiana (d’Orbigny), 1839. Pessagno, 1967, p. 346, pl. 72 , figs. 1-4, 7-9.

Globotruncana plummerae Gandolfi, 1955. Pessagno, 1967, p. 351, pl. 66 , figs. 3-8.

Globotruncana rosetta (Carsey), 1926. Pessagno, 1967, p. 352, pl. 70, figs. 9-12; pl. 73, figs. 5-8.

Globotruncana stuartiformis Dalbiez, 1955. Pessagno, 1967, p. 357, pl. 92 , figs. $1-3$; pl. 93 , figs. 6,7 .

Globotruncana subspinosa Pessagno, 1962. Pessagno, 1962, p. 362, pl. 2, figs. 7-9.

Globotruncana tricarinata (Quereau), 1893. Premoli Silva and Bolli, 1973 , p. 526.

Globotruncana ventricosa White, 1928. Premoli Silva and Bolli, 1973, p. 526, pl. 4, figs. 6, 7; Pessagno, 1967, p. 362, pl. 5, figs. 25, 26.

Globotruncanella havanensis (Voorwijk), 1937. Pessagno, 1967, p. 373 , pl. 84, figs. 1-3.

Globotruncanella sp. aff. G. petaloidea (Gandolfi), 1955. Pessagno, 1967 , p. 374 , pl. 82 , figs. $6-9$.

Guembelitria cretacea Cushman, 1933. Pessagno, 1967, p. 258, pl. 87, figs. 1-3.

Hedbergella flandrini Porthault, 1970. Porthault, in Donze, Porthault, et al., 1970 , p. 64 , pl. 10, figs. 1-3.

Hedbergella holmdelensis Olsson, 1964. Sliter, 1968, p. 100, pl. 15, figs. 6,8 .

Hedbergella monmouthensis Olsson, 1964. Sliter, 1968, p. 101, pl. 15, fig. 4 .

Hedbergella planispira (Tappan), 1940. Atlas, 1979/1, p. 139, pl. 27, 28.

Hedbergella simplex (Morrow), 1934. Atlas, 1979/1, p. 145, pl. 29, 30.

Heterohelix glabrans (Cushman), 1938. Sliter, 1968, p. 94, pl. 13, fig. 17.

Heterohelix globulosa (Eherenberg), 1839. Sliter, 1968, p. 94, pl. 14, figs. 1-3.

Heterohelix pulchra (Brotzen), 1936.Sliter, 1968, p. 95, pl. 14, figs. 4-6, 9.

Heterohelix punctulata (Cushman), 1938. Sliter, 1968, p. 96, pl. 14, fig. 7.

Heterohelix reussi (Cushman), 1938. Pessagno, 1967, p. 263, pl. 85, figs. 1-9; pl. 86, figs. 1, 2 .

Heterohelix striata (Ehrenberg), 1839. Sliter, 1968, p. 96, pl. 13, fig. 13. 
Marginotruncana sp. cf. M. marginata (Reuss), 1945. Atlas, 1979/2, p. 107, pl. 63,64 .

Marginotruncana pseudolinneiana Pessagno, 1967. Atlas, 1979/2, p. 123 , pl. 67,68 .

Marginotruncana renzi (Gandolfi), 1942. Atlas, 1979/2, p. 129, pl. 69. Marginotruncana sigali (Reichel), 1950. Atlas, 1979/2, p. 141, pl. 72, 73.

Planoglobulina acervulinoides (Egger), 1899. Pessagno, 1967, p. 271, pl. 87, fig. 14.

Praeglobotruncana aumalensis (Sigal), 1952. Atlas, 1979/2, p. 25, pl. 42.

Pseudoguemblenia costulata (Cushman), 1938. Pessagno, 1967, p. 26, pl. 79, fig. 1 ; pl. 88, figs. 8,9 .

Pseudoguemblenia excolata (Cushman), 1926. Pessagno, 1967, p. 266 , pl. 68 , figs. 4,5 ; pl. 90 , fig. 5 .

Pseudotextularia elegans (Rzehak), 1891. Pessagno, 1967, p. 268, pl. 75 , figs. $12-17$; pl. 88 , figs. 14-16 (and others).

Rotalipora greenhornensis (Morrow), 1934. Atlas, 1979/1, p. 85, pl. $12,13$.

Rugoglobigerina hantkeninoides Brönnimann, 1952. Bolli, Loeblich, and Tappan, 1957, p. 43, pl. 11, figs. 5a-c.

Rugoglobigerina hexacamerata Brönnimann, 1952. Pessagno, 1967, p. 364 , pl. 74 , fig. 4 ; pl. 9 , figs. 5-7.

Rugoglobigerina pilula Belford, 1960. Porthault, in Donze, Porthault et al., 1970, p. 68, pl. 9, figs. 21-23.

Rugoglobigerina rotundata Brönnimann, 1952. Pessagno, 1967, p. 365 , pl. 65 , figs. $1-4$; pl. 68 , figs. $1-3$.

Rugoglobigerina rugosa (Plummer), 1927, p. 366 , pl. 75 , figs. $2,3$.

Rugotruncana subcircumnodifer (Gandolfi), 1955. Pessagno, 1967, p. 369 , pl. 62, figs. 14-16; pl. 74, figs. 1-3.

Rugotruncana subpenneyi (Gandolfi), 1955. Pessagno, 1967, p. 370, pl. 76, figs. 12-14; pl. 91, figs. 8-15.

Schackoina cenomana (Schacko), 1897. Pessagno, 1967, p. 279, pl. 48 , fig. 6.

Schackoina multispinata (Cushman and Wickenden), 1930. Pessagno, 1967 , p. 180 , pl. 60 , fig. 1.

Whiteninella brittonensis (Loeblich and Tappan), 1961. Atlas, $1979 / 1$, p. 175 , pl. 37,38

\section{APPENDIX B}

\section{Samples from Site 462 Barren of Planktonic Foraminifers}

\section{Hole 462}

Core 40 , Section $3,146-150 \mathrm{~cm}$

Core $49, \mathrm{CC}$

Core 50, Section 2, 80-84 cm

Core 50 , Section $3,62-63 \mathrm{~cm}$

Core $50, \mathrm{CC}$

Core 51 , Section 3, 91-93 cm

Core 52 , Section 1, 98-101 cm (fine fraction)

Core 53 , Section $1,67-71 \mathrm{~cm}$

Core 54, Section 2, 67-72 cm

Core 55, Section 2, 61-66 cm

Core 55, Section 2, 71-73 cm

Core 55, Section 4, 55-59 cm

Core 55,CC (green)

Core 56 , Section 1, $1-5 \mathrm{~cm}$

Core 56, Section 1, 39-45 cm

Core 56 , Section $2,22-27 \mathrm{~cm}$

Core $56, \mathrm{CC}$

Core 57, Section 1, 2-4 cm

Core 57 , Section $2,20-26 \mathrm{~cm}$

Core 57, Section 2, 134-136 cm

Core 58 , Section $2,2-7 \mathrm{~cm}$

Core 58 , Section $3,78-82 \mathrm{~cm}$

Core 58, Section 3, 132-135 cm

Core 58, Section 4, 0-4 cm

Core 58 , Section $4,106-112 \mathrm{~cm}$

Core $58, \mathrm{CC}$

Core 59, Section 1, 23-28 cm

Core 59, Section 1, 90-98 cm

Core 59, Section 2, 114-121 cm

Core 59, Section 2, 136-141 cm

Core 59 , Section $3,1-3 \mathrm{~cm}$
Core $59, \mathrm{CC}$

Core 60 , Section 1, 46-49 cm

Core 65 , Section $1,18-21 \mathrm{~cm}$

Core 66, Section 1, 1-3 cm

Core 66 , Section 1, 6-8 cm

\section{Hole 462A}

Core $\mathrm{H} 3$, Section 3, 96-97 cm

Core 9 , Section $1,19 \mathrm{~cm}$ (thin section)

Core 9, Section 1, 35-41 cm

Core 9 , section $1,90 \mathrm{~cm}$ (thin section)

Core 9, Section 1, 140-144 cm

Core 9 , Section $3,26-30 \mathrm{~cm}$

Core 9, Section $4,17 \mathrm{~cm}$ (thin section)

Core 10, Section 1, 47-52 cm

Core 10 , Section $1,47 \mathrm{~cm}$ (thin section)

Core 10 , Section 1, 67-72 cm

Core 10, Section 3, 121-126 cm

Core 11, Section 1, 41-42 cm

Core 11, Section 1, 67-70 cm

Core 11, Section 1, 123-127 cm

Core 11, Section 1, $140 \mathrm{~cm}$ (thin section)

Core 11, Section 2, 6-9 cm

Core $11, \mathrm{CC}$

Core 12, Section 1, 62-67 cm

Core 12, Section 2, 4-10 cm

Core $12, \mathrm{CC}$

Core 13, Section 1, 1-5 cm

Core 13, Section 1, $19 \mathrm{~cm}$ (thin section)

Core 13, Section 1, 87-92 cm

Core 13, Section 2, 3-7 cm

Core 13, Section 2, 26-28 cm

Core 13, Section 2, $65 \mathrm{~cm}$ (thin section)

Core 13, Section 2, 123-128 cm

Core $13, \mathrm{CC}$

Core 14, Section 1, 29-32 cm

Core 14, Section 1, 90-95 cm

Core 21, Section 1, 1-5 cm (three pebbles)

Core 21, Section 2, 10-11 cm (thin section)

Core 22, Section 2, 11-14 cm

Core 22, Section 2, 85-89 cm

Core 23 , Section $1,8-10 \mathrm{~cm}$

Core 23 , Section $2,80-82 \mathrm{~cm}$

Core 32, Section 1, 61-63

Core 32 , Section 1, $98 \mathrm{~cm}$ (thin section)

Core $32, \mathrm{CC}$

Core $33, \mathrm{CC}$

Core $35, \mathrm{CC}$

Core 40 , Section 1, 90-95 cm

Core 40 , Section 1, 148-150 cm

Core 40, Section 2, 10-13 cm

Core 41, Section 7, 134-139 cm

Core 41 , Section $8,6-9 \mathrm{~cm}$

Core 42 , Section $1,34-36 \mathrm{~cm}$

Core 42, Section 1, 42-46 cm

Core 42 , Section 1, 63-68 cm

Core 42, Section 2, 19-22 cm

Core 42 , Section $2,47-51 \mathrm{~cm}$

Core 43, Section 1, 36-40 cm

Core 43, Section 2, 50-54 cm

Core 43, Section 2, 105-109 cm

Core 43, Section 3, 31-35 cm

Core 43, Section 3, 49-54 cm

Core $43, \mathrm{CC}$

Core 44 , Section 1, 1-3 cm

Core $44, \mathrm{CC}$

Core 46, Section 1, 1-3 cm

Core 79 , Section $6,1-2 \mathrm{~cm}$

Core 79, Section 6, 3-5 cm

Core 80 , Section $1,1-2 \mathrm{~cm}$

Core 80 , Section $1,4-5 \mathrm{~cm}$

Core 80 , Section $1,110-115 \mathrm{~cm}$

Core 80, Section 2, 108-110 cm 


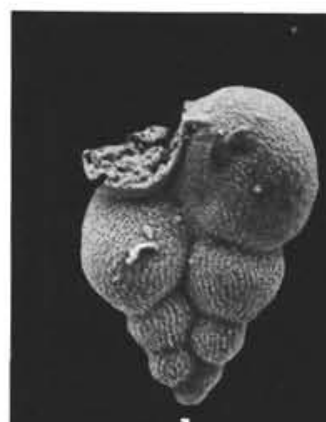

1

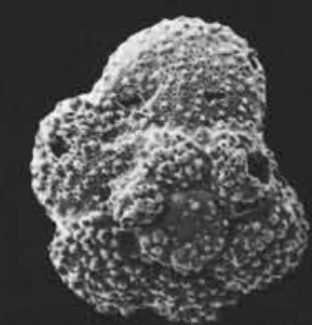

6

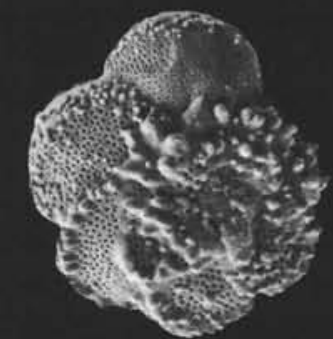

10

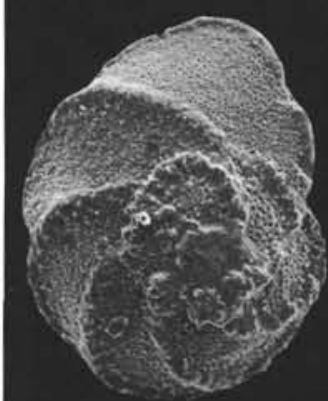

14
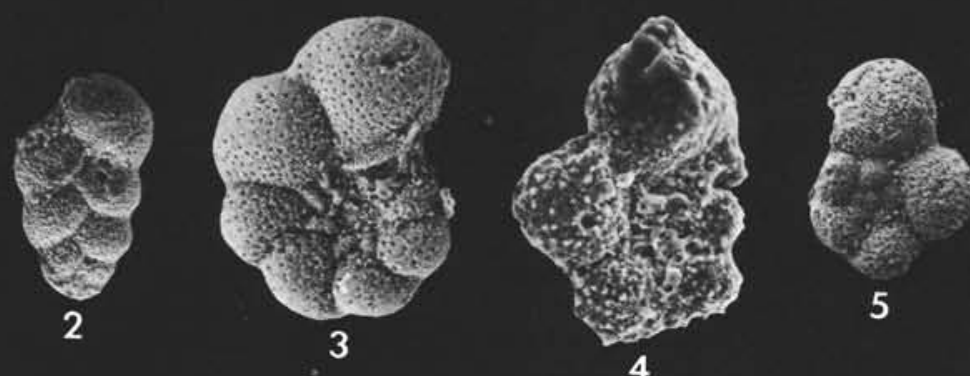

5

4
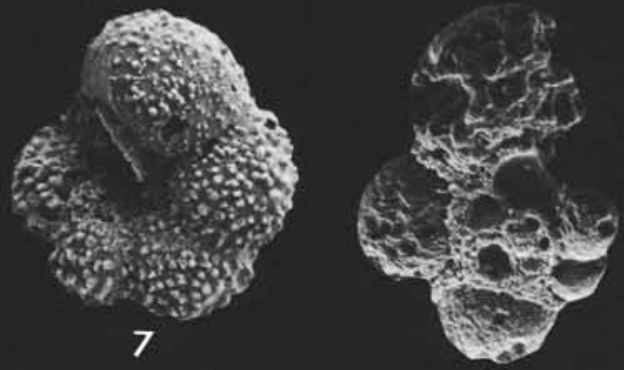

8

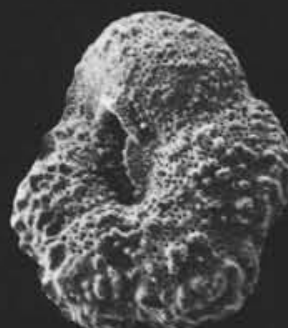

11

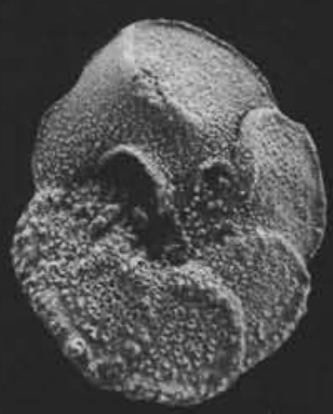

15

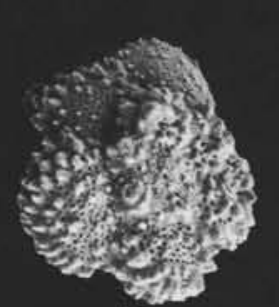

12

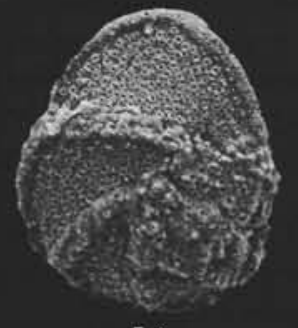

16

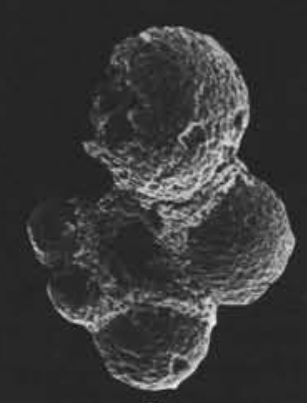

9

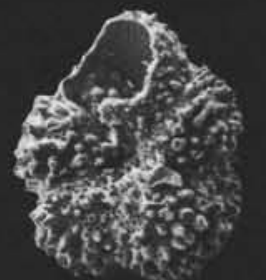

13
Plate 1. Foraminifers. (All except Figure $4 \times 128$.)

Figures 1, 2. Heterohelix reussi (Cushman). Sample 462-57-3, 100$108 \mathrm{~cm}$. 1. Large specimen. 2. Typical small specimen.

Figure 3. Globigerinelloides caseyi (Bolli, Loeblich, and Tappan). Sample 462-57-3, 100-108 cm.

Figure 4. Globigerinelloides cepedai (Obregon). Sample 462-57-3, $53-55 \mathrm{~cm}, \times 300$.

Figures 5, 8, 9. Hedbergella flandrini Porthault. 5, 8. Sample 462-57$3,53-55 \mathrm{~cm}$. 9. Sample 462-57,CC.
Figures 6, 7. Praeglobotruncana aumalensis (Sigal). Sample 462-57-3, $100-108 \mathrm{~cm}$. Spiral and umbilical views of typical specimens.

Figures 10, 11. Praeglobotruncana sp. aff. P. aumalensis (Sigal). Sample 462-57-3, 100-108 cm. Spiral and umbilical views.

Figures 12, 13. Praeglobotruncana aumalensis (Sigal). Sample 462$57-3,100-108 \mathrm{~cm}$. Spiral and umbilical views of primitive specimen.

Figures 14-17. Rotalipora greenhornensis (Morrow). Sample 462$57-3,100-108 \mathrm{~cm}$. Spiral and umbilical views. 


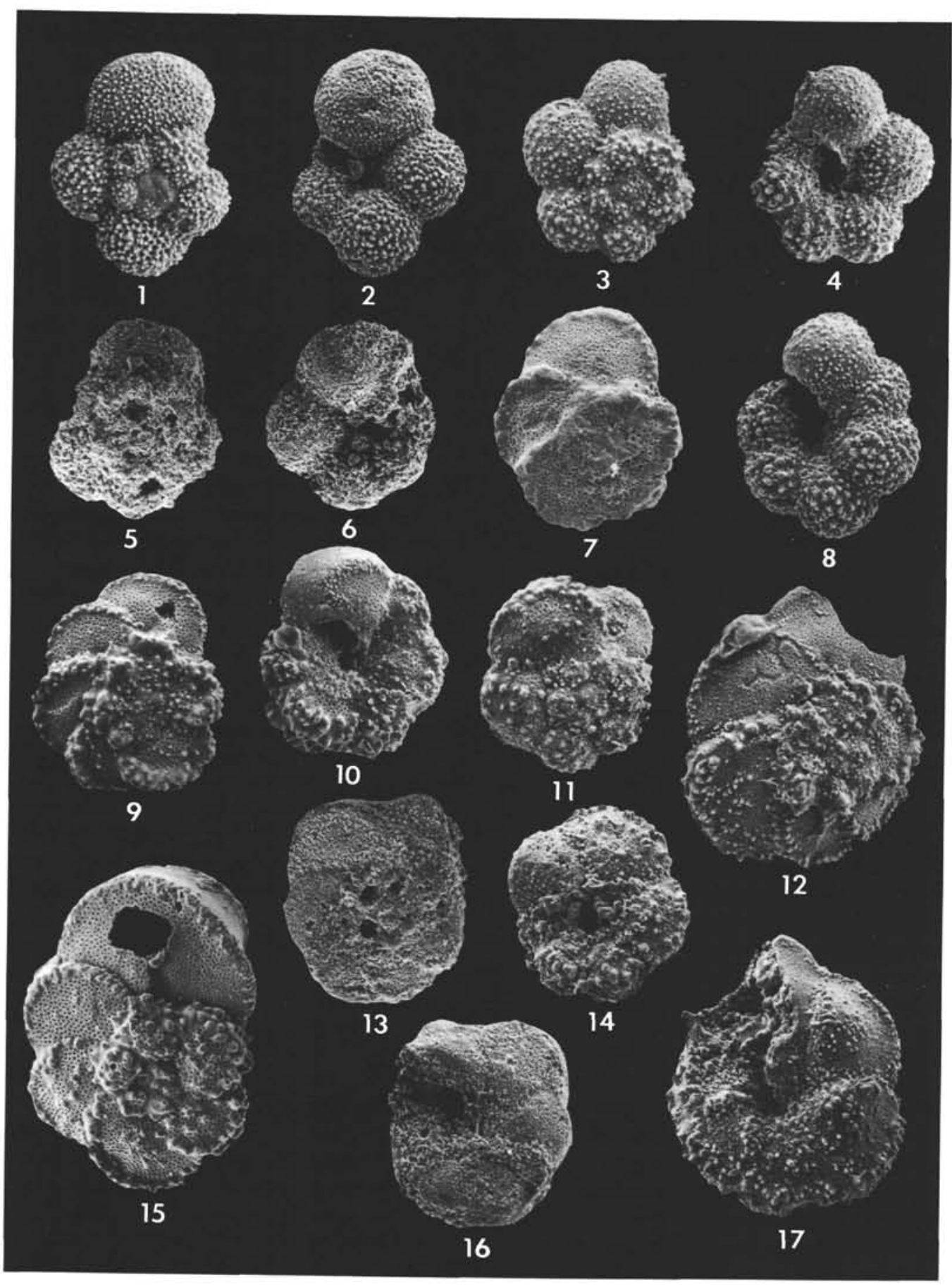

Plate 2. Foraminifers. (All $\times 128$.)

Figures 1, 2. Archaeoglobigerina blowi Pessagno. Sample 462-57-3, $100-108 \mathrm{~cm}$. Spiral and umbilical views.

Figures 3, 4, 8. Archaeoglobigerina bosquensis Pessagno. Sample $462-57-3,100-108 \mathrm{~cm}$. Spiral and umbilical views.

Figures 5, 6. Dicarinella algeriana (Caron). Sample 462-57,CC. Spiral and umbilical views.
Figures 9, 10. Dicarinella canaliculata (Reuss). Sample 462-57-3, $100-108 \mathrm{~cm}$. Spiral and umbilical views.

Figures 11-14. Marginotruncana sp. cf. M. marginata (Reuss). Sample 462-57-3, 100-108 cm. Spiral and umbilical views.

Figures 12, 17. Marginotruncana renzi (Gandolfi). Sample 462-57-3, $100-108 \mathrm{~cm}$. Spiral and umbilical views.

Figures 13, 15, 16. Marginotrunacan pseudolinneiana Pessagno. Sample 462-57,CC. 13. Spiral view of large specimen. 15, 16. Spiral and umbilical views of corroded specimen. 